\title{
NRAMPI (SLC11A1) Gene-1703 G/A Polymorphisms as Prognostic and Diagnostic Marker of Rheumatoid Arthritis in Egyptian Population
}

\author{
Atef E. Abd El-Baky ${ }^{1}$, Ahmad Salahuddin ${ }^{2 *}$ and Mohamed Katary ${ }^{3}$ \\ ${ }^{1}$ Biochemistry Department, Faculty of Pharmacy, Port Said University, Egypt \\ ${ }^{2}$ Biochemistry Department, Faculty of Pharmacy, Damanhour University, Egypt \\ ${ }^{3}$ Department of Pharmacology and Toxicology, Faculty of Pharmacy, Damanhour University \\ *Corresponding author: Ahmad Salahuddin, Biochemistry Department, Faculty of Pharmacy, Damanhour University, Egypt, E-mail: ahmad.dr@live.com
}

Received date: January 31, 2017; Accepted date: February 18, 2017; Published date: February 24, 2017

Copyright: (c) 2017 El-Baky AEA, et al. This is an open-access article distributed under the terms of the Creative Commons Attribution License, which permits unrestricted use, distribution, and reproduction in any medium, provided the original author and source are credited.

\begin{abstract}
Rheumatoid arthritis (RA) is an autoimmune disease with difficulty to diagnose. The association of natural resistance-associated macrophage protein-1 (NRAMP-1) gene polymorphisms with rheumatoid arthritis (RA) is the aim of this study.

Methods: Two hundred individuals who were divided into two groups: RA patients group (100 Patients with RA) and control group: (100 apparently healthy subjects). NRAMP1 polymorphisms were determined by the polymerase chain reaction/restriction fragment length polymorphism (PCR/RFLP) method, including D543N.

Results: Rheumatoid arthritis patients demonstrated significant increase in C-reactive protein (CRP), Rheumatoid Factor Ab, Human cartilage oligomeric matrix protein (COMP) and Anti-Cyclic Citrullinated Peptide (anti-CCP) in comparison to normal. Clinical disease activity index (CDAl) and the radiological erosion score of joints in RA patients were $29.8 \pm 5.3$ and $60.03 \pm 38.71$ respectively. The $G / G, G / A$ and $A / A$ genotypes were 64,33 , and $3 \%$ respectively in RA patients and were 60,25 , and $15 \%$ respectively in controls with a significant difference between RA patients and controls. The CDAI and radiological erosion score of joints had the least values in NN followed by DN while DD patients had the highest levels. The patients with phenotype DD had a grade III of disease in 40 patients and grade IV in 21 patients while grade II found in three patients. However, in patients with phenotype DN, the grading of disease II, III and IV were found to be 10, 20 and 3 respectively. All patients with NN phenotype showed a grade II of disease. There was a significant difference in percentage between RA patients and controls as regard to $G$ or $A$ alleles distribution. The nodule associated with $G / G$ genotype in $58.8 \%$ while bone erosion associated with $\mathrm{G} / \mathrm{G}$ genotype in $65 \%$ of RA patients.
\end{abstract}

Conclusion: The present study showed that NRAMP1 1703G (543D) is a risk factor for the development of RA. The estimated NRAMP1 $1703 \mathrm{G}$ haplotype is associated with susceptibility to RA. In RA patients with 1703A, development of rheumatoid nodule is absent.

Keywords: Rheumatoid arthritis; NRAMP1; SLC11A1; CRP; COMP; Anti-CCP; RF-Ab

\section{Introduction}

Rheumatoid arthritis (RA) is an autoimmune disease involving an antibody response to Citrullinated proteins (ACPA) [1] and Ig-Fc (rheumatoid factor, RF) [2]. RA is characterized by joint inflammation that lead to joint destruction which decrease its functional capacity, work disability, and reduce quality of life [3].

Natural resistance-associated macrophage protein 1 gene (NRAMP1), also named as solute carrier family 11-member A1 gene (SLC11A1), plays a role in susceptibility to RA [4]. NRAMP1 has pleiotropic effects on macrophage function, including up-regulation of chemokine/cytokine gene, tumor necrosis factor- $\alpha$ (TNF- $\alpha$ ), interleukin $1 \beta$ (IL-1 $\beta$ ), inducible nitric oxide synthase (iNOS), and major histocompatibility complex (MHC) expression as well as tumoricidal activity and antimicrobial activity [5].
NRAMP1 was demonstrated to be related to susceptibility to RA [6] and is associated with behavioral and immune response to stress [7]. However, a report about the association of this gene with RA is still unavailable in Egypt.

The aim of this study is to investigate the associations of NRAMP1 polymorphisms with development and clinical manifestations of Egyptian RA patients.

\section{Materials and Methods}

This study was carried out in the rheumatology and rehabilitation outpatient clinics and inpatient departments of Benha University hospital and Nozha international hospital, Cairo, Egypt.

This study includes 200 non-smoker males with age ranged between 35-60 years and they were divided into 2 groups:

A-RA patients group: 100 male patients with RA, their disease duration ranged between 8 months-10 years. 
Page 2 of 4

B-The control group: 100 apparently healthy male subjects carefully chosen matched for age with the RA patients.

All the patients were subjected to:

I-Thorough clinical examination: Clinical disease activity index (CDAI) and the radiological erosion score of joints were calculated.

II-Laboratory investigations: C-reactive Protein (CRP), Cartilage Oligomeric Matrix Protein (COMP), Rheumatoid Factor Ab, and AntiCyclic Citrullinated Peptide (anti-CCP) were assessed in serum samples.

NRAMP1 polymorphisms were determined by the polymerase chain reaction/restriction fragment length polymorphism method, including D543N (at codon 543 in exon 15; G or A at nucleotide 1703. The sequences of primers forward 5'GCATCTCCCCAATTCATGGT-3' and reverse 5'AACTGTCCCACTCTATCCTG-3' and restriction enzyme is Ava. Amplification was performed in a total volume of $100 \mathrm{ml}$, containing reaction buffer (Roche Diagnostics), $100 \mathrm{ng}$ template DNA, $20 \mathrm{pmol}$ each primer, $200 \mathrm{~mm}$ each of the four dNTPs and 2 units Taq/Pwo DNA polymerase. The DNA was denatured at $94^{\circ} \mathrm{C}$ for 4 min followed by 30 cycles at $94^{\circ} \mathrm{C}$ for $30 \mathrm{~s}, 60^{\circ} \mathrm{C}$ for $60 \mathrm{~s}$, and $72^{\circ} \mathrm{C}$ for $90 \mathrm{~s}$, and a final extension step at $72^{\circ} \mathrm{C}$ for $4 \mathrm{~min}$. cycling was performed in a thermal cycler (Perkin-Elmer).

Statistical analysis: The chi-square test with Yates' correction (for $2 \times$ 2 contingency tables) or Fisher's exact test was used for statistical analysis. Odds ratio (OR) and its $95 \%$ confidence interval (CI) was calculated by using SPSS statistic program.

\section{Results}

Table 1 shows CDAI in RA patients that ranged between 18:36 with mean \pm SD value of $29.8 \pm 5$.3. The radiological erosion score of joints in RA patients, which lies between $8-140$ with mean \pm SD value of $60.03 \pm 38.71$

\begin{tabular}{|l|l|l|}
\hline & CDAI & $\begin{array}{l}\text { Radiological erosion score } \\
\text { of joints of rheumatoid } \\
\text { arthritis }\end{array}$ \\
\hline No. of patients & 100 & 100 \\
\hline Range & $18-36$ & $8-140$ \\
\hline Mean & $2.98 \pm 5.3$ & $60.03 \pm 38.7$ \\
\hline
\end{tabular}

Table 1: CDAI and radiological erosion score of joints of rheumatoid arthritis.

The NRAMP1 gene has three forms according to the sequence of polynucleotide in DNA strand. The base numbered 1703 may be Guanine $(G)$ and may be transverse into Adenine (A) subsequently the amino acid changed in NRAMP1 protein and hence affect the status of RA.

Table 2 shows genotype frequencies of NRAMP1 (1703) gene polymorphisms in patients with RA as well as controls. As known, every gene has two alleles G/G, G/A and A/A which appear in phenotype DD, DN and NN. In the NRAMP1 protein, the amino acid number 543 substituted as the result of NRAMP1 gene polymorphism. The G/G genotype found in $64 \%$ in RA patients while was $60 \%$ in controls. The G/A genotype was $33 \%$ in RA patients while was $25 \%$ in controls. The A/A genotype observed in $3 \%$ in RA patients while was
$15 \%$ in controls. There is a significant difference in the percentage between RA patients and controls ( $\mathrm{p}=0.001)$.

Table 3 shows CDAI and radiological erosion score of joints of rheumatoid arthritis as regard NRAMP1 genotype. As shown, CDAI and radiological erosion score of joints have least values in $\mathrm{NN}$ followed by DN while DD patients have the highest levels.

\begin{tabular}{|l|l|l|l|}
\hline NRAMP1 genotype & $\begin{array}{l}\text { RA } \\
\mathbf{n = 1 0 0}\end{array}$ & $\begin{array}{l}\text { Controls } \\
\mathbf{n = 1 0 0}\end{array}$ & $\mathbf{p}$ \\
\hline $1703(\mathrm{D} 543 \mathrm{~N})$ & & 60 & 0.001 \\
\hline G/G (D/D) & 64 & 25 & \\
\hline G/A (D/N) & 33 & 15 & \\
\hline A/A (N/N) & 3 & & \\
\hline
\end{tabular}

Table 2: Genotype frequencies of NRAMP1 polymorphisms in patients with rheumatoid arthritis and controls.

\begin{tabular}{|c|c|c|c|}
\hline NRAMP1 phenotype & $\mathbf{N}$ & 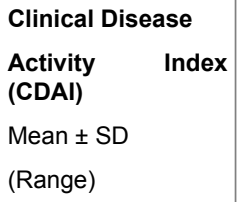 & $\begin{array}{l}\text { Radiological erosion } \\
\text { Score } \\
\text { Mean } \pm \text { SD } \\
\text { (Range) }\end{array}$ \\
\hline DD & $\begin{array}{l}6 \\
4\end{array}$ & $\begin{array}{l}30.8 \pm 4.6 \\
(18-36)\end{array}$ & $\begin{array}{l}62.84 \pm 39.14 \\
(8.00-125.00)\end{array}$ \\
\hline DN & $\begin{array}{l}3 \\
3\end{array}$ & $\begin{array}{l}28.7 \pm 5.7^{*} \\
(20-35)\end{array}$ & $\begin{array}{l}51.20 \pm 39.06^{*} \\
(15.00-140.00)\end{array}$ \\
\hline NN & 3 & $\begin{array}{l}20 \pm 0.6 \\
(19-21)\end{array}$ & $\begin{array}{l}10.00 \pm 1.20 \\
(8.00-12.00)\end{array}$ \\
\hline
\end{tabular}

Table 3: Clinical Disease Activity Index (CDAI), Radiological erosion score of joints of rheumatoid arthritis as regard NRAMP1 genotype.

Table 4 shows the grades of disease activity in different phenotypes patients. The patients with phenotype (DD) have a grade III of disease in 40 patients and grade IV in 21 patients while grade II found in three patients. However, in patients with phenotype (DN), the grading of disease II, III and IV found to be 10, 20 and 3 respectively. The patient with $(\mathrm{NN})$ phenotype shows a grade II of disease.

\begin{tabular}{|l|l|l|l|l|l|}
\hline & \multicolumn{5}{|l|}{ NRAMP1 phenotype } \\
\cline { 2 - 6 } & & DD (64) & DN (33) & NN (3) & Total (100) \\
\hline & II & $3(4.7)$ & $10(30.3)$ & $3(100)$ & 16 \\
\cline { 2 - 6 } $\begin{array}{l}\text { Grades of } \\
\text { disease } \\
\begin{array}{l}\text { activity of } \\
\text { the patients }\end{array}\end{array}$ & III & $40(62.5)$ & $20(60.6)$ & $0(0)$ & 60 \\
\cline { 2 - 6 } & IV & $21(32.8)$ & $3(10.1)$ & $0(0)$ & 24 \\
\hline
\end{tabular}

Table 4: Cross tabulation between NRAMP1 genotype and Grades of disease activity of the patients.

Table 5 shows the allele frequencies of NRAMP1 (1703G/A) polymorphisms in patients with rheumatoid arthritis and controls. 
Page 3 of 4

There is a significant difference in percentage between RA patients and controls as regard to $\mathrm{G}$ or $\mathrm{A}$ alleles distribution.

Table 6 shows association of genotype with the clinical manifestation of RA patients. The nodule associated with $\mathrm{G} / \mathrm{G}$ genotype in $58.8 \%$ while bone erosion associated with $\mathrm{G} / \mathrm{G}$ genotype in $65 \%$ of RA patients.

\begin{tabular}{|l|l|l|l|l|l|}
\hline $\begin{array}{l}\text { NRAMP1 } \\
\text { haplotype }\end{array}$ & RA (2n=50 (\%)) & $\begin{array}{l}\text { Controls } \\
\text { (\%)) }\end{array}$ & $\mathbf{( 2 n = 5 0}$ & $\mathbf{P}$ & OR (95\% Cl) \\
\hline G (543D) & $161(80)$ & $145(72.5)$ & & 0.048 & $\begin{array}{l}1.5 \\
4.3)\end{array}$ \\
\hline A (543N) & $39(20)$ & $55(27.5)$ & & & \multicolumn{2}{|l|}{} \\
\hline
\end{tabular}

Table 5: Allele frequencies of NRAMP1 (1703G/A) polymorphisms in patients with rheumatoid arthritis and controls.

\begin{tabular}{|l|l|l|l|l|}
\hline \multicolumn{2}{|c|}{} & \multicolumn{2}{l|}{ Nodule } & \multicolumn{2}{l|}{ Bone erosion } \\
\cline { 2 - 5 } & $+(n=17)$ & $-(n=83)$ & $+(n=60)$ & $-(n=40)$ \\
\hline G/G (543 D/D) & $10(58.8)$ & $54(65.1)$ & $39(65)$ & $25(32.5)$ \\
\hline G/A (543 D/N) & $6(35.3)$ & $27(32.5)$ & $18(30)$ & $15(37.5)$ \\
\hline A/A (543 N/N) & $1(5.9)$ & $2(2.4)$ & $3(5)$ & $0(0)$ \\
\hline
\end{tabular}

Table 6: Associations of NRAMP1 gene polymorphisms with clinical manifestations of RA.

Table 7 show significant increase in both CRP, Rheumatoid Factor $\mathrm{Ab}, \mathrm{COMP}$ and anti-CCP of RA patients in comparison to normal $(\mathrm{p}<0.001)$.

\begin{tabular}{|l|l|l|}
\hline & Control & RA \\
\hline CRP $(\mathrm{ng} / \mathrm{ml})$ & $3.04 \pm 0.27$ & $254.3 \pm 4.95^{*}$ \\
\hline Rheumatoid Factor Ab $[\mathrm{U} / \mathrm{ml}]$ & $14.67 \pm 0.41$ & $36.84 \pm 1.17^{*}$ \\
\hline COMP $(\mathrm{ng} / \mathrm{ml})$ & $5.41 \pm 0.33$ & $79.3 \pm 2.01^{*}$ \\
\hline Anti-CCP $(\mathrm{ng} / \mathrm{ml})$ & $18.3 \pm 0.92$ & $285 \pm 9.2^{*}$ \\
\hline
\end{tabular}

Table 7: CRP, Rheumatoid Factor Ab, COMP and anti-CCP of RA patients in comparison to normal.

\section{Discussion}

Rheumatoid arthritis was characterized by joint inflammation which lead to destruction and loss functions of joint [3]. This disease was accompanied by elevation of serum biomarker levels. Our results referred to an elevation of serum COMP level and rheumatoid factor $\mathrm{Ab}$ in confirm with previous studies. An increase in serum COMP level is a biomarker for cartilage turnover in human joint diseases $[8,9]$.

CRP marker is used to measure the level or degree of inflammation in patients with RA [10]. The present study demonstrated that both CRP and Anti-CCP marker were elevated in RA patients in agreement with others who demonstrated that the increasing of CRP levels are associated with decreased functional ability [11] and with increased disease activity and radiological progression in RA [12]. CRP is more specific marker of inflammation and joint damage [13]. C reactive protein, reflecting inflammation, COMP and a marker of cartilage turnover with putative roles in disease chronicity [8].

In addition, this study demonstrated that the NRAMP1 polymorphisms were associated with susceptibility to clinical manifestation of RA. NRAMP1 is located on chromosome $2 \mathrm{q} 35$. NRAMP1 expression is primarily in tertiary granules of polymorph nuclear cell and macrophage. It is recruited from tertiary granules to the phagosomal membrane on phagocytosis [14]. NRAMP1 is a proton/divalent cations antiporter [15]. It fluxes divalent cations in either direction depending on the $\mathrm{pH}$ on either side of the membrane [16]. In late endosomes/lysosomes, NRAMP1 delivers divalent cations from the cytoplasm to this acidic compartment. Fenton reaction uses ferrous iron to generate toxic hydroxyl radicals, which are associated with killing intracellular pathogen [17]. The expression of iNOS and generation of toxic NO may be influenced by the polymorphisms of NRAMP1 [18]. Mutation of NRAMP1 also impairs phagosomal acidification, which is related to intracellular infection. Vidal showed that a mutation at amino acid 169 of NRAMP1 makes mice more susceptible to infection of many pathogens [19]. NRAMP1 polymorphisms are also related to many human infectious diseases, including pulmonary tuberculosis (TB), leprosy, human immunodeficiency virus infection, visceral leishmaniosis, and meningococcal meningitis $[4,20]$. Infection may be a triggering factor for development of RA.

NRAMP1 is considered as a candidate gene for RA also because it up-regulates the production of proinflammatory cytokines TNF- $\alpha$ and IL-1 $\beta$, which are known to play important roles in the pathogenesis of RA. NRAMP1 polymorphisms that lead to higher levels of cytokines in activated macrophages may predispose individuals to development and perpetuation of autoimmune diseases [20]. The up-regulation of MHC by NRAMP1 may also be associated with susceptibility to RA.

This study demonstrated that NRAMP1 $1703 \mathrm{G}$ (543D) is associated with the development of RA. This finding is different from those of $[21,22]$. Singal and his colleagues showed that NRAMP1 1703 (D543N) protects against the development of RA. In contrast, Yang and his team revealed that $1703 \mathrm{~A}(543 \mathrm{~N})$ was a risk factor for RA. We also found that NRAMP1 1703 (D543N) is associated with susceptibility to RA. A similar finding was also revealed by Liu et al. [19]. The NRAMP1 823C/T polymorphism is a silent substitution and $1703 \mathrm{G} / \mathrm{A}$ (D543N) is a missense substitution (aspartic acid $\rightarrow$ asparagine). The protein function may be changed after substitution of negatively charged aspartic acid with an uncharged asparagine.

\section{Conclusions}

Rheumatoid arthritis had elevated level of some biomarker like Creactive protein (CRP), rheumatoid factor $\mathrm{Ab}$, cartilage oligomeric matrix protein, COMP and anti-CCP. NRAMP1 1703G (543D) is risk factor for the development of RA. The estimated NRAMP1 1703G haplotype is associated with susceptibility to RA. In RA patients with $1703 \mathrm{~A}$, development of rheumatoid nodule is absent.

\section{Funding}

The study was funded by departmental resources. 
Citation: El-Baky AEA, Salahuddin A (2017) NRAMPI (SLC11A1) Gene-1703 G/A Polymorphisms as Prognostic and Diagnostic Marker of Rheumatoid Arthritis in Egyptian Population . J Allergy Ther 8: 246. doi:10.4172/2155-6121.1000246

Page 4 of 4

\section{Acknowledgment}

The authors record their great thanks to all departments of Benha University Hospital and El-Nozha International Hospital, Cairo, Egypt, for helping and facilitating the performance of this work.

\section{References}

1. Barton A, Worthington J (2009) Genetic susceptibility to rheumatoid arthritis: an emerging picture. Arthritis Rheum 61: 1441-1446.

2. Newkirk MM (2002) Rheumatoid factors: host resistance or autoimmunity?. Clin Immunol 104: 1-13.

3. Sokka T (2009) Long-term outcomes of rheumatoid arthritis. Current Opin Rheumatol 21: 284-290.

4. Ates O, Dalyan L, Musellim B, Hatemi G, Turker H, et al. (2009) NRAMP1 (SLC11A1) gene polymorphisms that correlate with autoimmune versus infectious disease susceptibility in tuberculosis and rheumatoid arthritis. Int J Immunogenet 36: 15-19.

5. Vejbaesya S, Chierakul N, Luangtrakool P, Sermduangprateep C. NRAMP1 and TNF-(alpha) polymorphisms and susceptibility to tuberculosis in Thais. Respirology 12: 202-206.

6. Pacheco AG, Moraes MO (2009) Genetic polymorphisms of infectious diseases in case-control studies. Dis Markers 27: 173-186.

7. Evans CA, Harbuz MS, Ostenfeld T, Norrish A, Blackwell JM, et al. (2001) Nramp1 is expressed in neurons and is associated with behavioural and immune responses to stress. Neurogenetics 3: 69-78.

8. Saxne T, Heinegard D (1992) Cartilage oligomeric matrix protein: a novel marker of cartilage turnover detectable in synovial fluid and blood. $\mathrm{Br} \mathrm{J}$ Rheumatol 31: 583-591.

9. Neidhart M, Hauser N, Paulsson M, DiCesare PE, Michel BA, et al. (1997) Small fragments of cartilage oligomeric matrix protein in synovial fluid and serum as markers for cartilage degradation. $\mathrm{Br} \mathrm{J}$ Rheumatol 36: 1151-1160.

10. Garnero P, Geusens P, Landewé R (2003) Biochemical markers of joint tissue turnover in early rheumatoid arthritis. Clin Exp Rheumatol 21: S54-58.

11. Mallya RK, De Beer FC, Berry H, Hamilton ED, Mace BE, et al. (1982) Correlation of clinical parameters of disease activity in rheumatoid arthritis with serum concentrations of C-reactive protein and erythrocyte sedimentation rate. J Rheumatol 9: 224-228.
12. Dessein PH, Joffe BI, Stanwix AE (2004) High sensitivity C-reactive protein as a disease activity marker in rheumatoid arthritis. J Rheumatol 31: 1095-1097.

13. Skogh T, Gustafsson D, Kjellberg M, Husberg M (2003) Twenty eight joint count disease activity score in recent onset rheumatoid arthritis using $\mathrm{C}$ reactive protein instead of erythrocyte sedimentation rate. Ann Rheum Dis 62: 681-682.

14. Canonne-Hergaux F, Calafat J, Richer E, Cellier M, Grinstein S, et al. (2002) Expression and subcellular localization of NRAMP1 in human neutrophil granules. Blood 100: 268-275.

15. Forbes JR, Gros P (2003) Iron, manganese, and cobalt transport by Nramp1 (Slc1 1a1) and Nramp2 (Slc11a2) expressed at the plasma membrane. Blood 102: 1884-1892.

16. Jabado N, Jankowski A, Dougaparsad S, Picard V, Grinstein S, et al. (2000) Natural resistance to intracellular infections: natural resistanceassociated macrophage protein 1 (Nramp1) functions as a $\mathrm{pH}$-dependent manganese transporter at the phagosomal membrane. J Exp Med 192: 1237-1248.

17. Blackwell JM, Goswami T, Evans CA, Sibthorpe D, Papo N, et al. (2001) SLC11A1 (formerly NRAMP1) and disease resistance. Cell Microbiol 3: 773-784.

18. Arias M, Rojas M, Zabaleta J, Rodriguez JI, Paris SC, et al. (1997) Inhibition of virulent mycobacterium tuberculosis by $\mathrm{Bcg}(\mathrm{r})$ and $\mathrm{Bcg}(\mathrm{s})$ macrophages correlates with nitric oxide production. J Infect Dis 176: 1552-1558.

19. Liu J, Fujiwara TM, Buu NT, Sanchez FO, Cellier M, et al. (1995) Identification of polymorphisms and sequence variants in the human homologue of the mouse natural resistance-associated macrophage protein gene. Am J Hum Genet 56: 845-853.

20. Merza M, Farnia P, Anoosheh S, Varahram M, Kazampour M, et al. (2009) The NRAMPI, VDR and TNF-alpha gene polymorphisms in Iranian tuberculosis patients: the study on host susceptibility. Braz J Infect Dis 13: 252-256.

21. Singal DP, Li J, Zhu Y, Zhang G (2000) NRAMP1 gene polymorphisms in patients with rheumatoid arthritis. Tissue Antigens 55: 44-47.

22. Yang YS, Kim SJ, Kim JW, Koh EM (2000) NRAMP1 gene polymorphisms in patients with rheumatoid arthritis in Koreans. J Korean Med Sci 15: 83-87. 